\title{
Myth in the History and Modern World of She People: The Preservation, Transmission and Uses of Epic Stories in the Ethnic Group of South-Eastern China
}

\author{
Sai Yan ${ }^{1}$ \\ ${ }^{1}$ School of History and Culture, Minzu University of China, Beijing, China \\ Correspondent: Sai Yan, School of History and Culture, Minzu University of China, Beijing, China. E-mail: \\ yansai96@hotmail.com
}

Received: January 12, 2018

Accepted: January 21, 2018

Online Published: February 8, 2018

doi:10.5539/ach.v10n1p76

URL: http://dx.doi.org/10.5539/ach.v10n1p76

\begin{abstract}
This article gives an ethnographic account of the epic tradition of She people in China, noting the dual transmission methods of stories, in which the core of the story is preserved in pictorial depictions within primarily sacred contexts, whilst more flexible oral retellings fit the stories to the daily life of the She in modern China. The article contrasts western views of myth as a feature of a pre-modern way of life which has lost its relevance in the modern world with common understandings of myth in China as factually based and relevant to contemporary life. The article shows how the She deploy their mythic heritage to reinforce their ethnic identity and to pursue material interests within the context of modernizing Chinese state, numerically and politically dominated by the Han majority, and draws upon the work of Claude Lévi-Strauss to suggest that myth remains an important component of Chinese modernity.
\end{abstract}

Keywords: China, epic, modernity, myth, She ethnic group

\section{Introduction}

Although numerous scholars have discussed the meaning of myth (e.g. Cruz \& Frijhoff, 2009), there is little agreement on a clear definition of the term. The origins and meanings of myths have generated heated debates in the fields of the humanities and social sciences throughout the world. This paper will first consider western scholarship on myth, showing that from Tylor to Lévi-Strauss, western theorists have generally contrasted myth explicitly with science, associating myth primarily with pre-modern societies, and science with the modern. It will then note the somewhat different attitudes to myth prevalent in modern China, and will introduce my fieldwork, which focused on the mythology of the She people from the southeast of the country. By examining the development of She mythology over history by consideration of written accounts, epic retellings and pictorial representations, the paper will argue that the She have creatively moulded and remoulded their mythology over time in order to preserve their distinctive ethnic identity in the face of Han domination, and that they continue to do so in the modern world. In so doing, it will show that in China, rather than a transition from mythical to scientific thought as envisaged by Tylor, we see the coexistence and interaction of these two modes of thought, in a modernising context within which myth remains centrally relevant to She identity and well-being. It will suggest that this survival justifies Lévi-Strauss's assertion that myth survives in the modern world and is as rational as science in its own way.

\section{Myth in Western thought}

A general dictionary defines myth as: a traditional narrative usually involving supernatural or imaginary persons and often embodying popular ideas on natural or social phenomena (Fowler \& Fowler, 1995). In etymological terms, the origin of the English word 'myth' can be traced back to the Greek word $\mu$ v́ $\theta$ 'oc. (mythos). Vernant (1979) notes that this word originally meant formulated speech, so it could include a narrative story, a communicative dialogue or the enunciation of a plan and it is clear that this term has a strong relationship with oral expression. According to Vernant (ibid), most of the Greek narratives that we know were passed down orally, so no original storyteller can be identified, and they may have been changed repeatedly in the telling, rendering the character as well as the plot of myth indeterminate. 
Between the eighth and fourth centuries B.C., the Archaic period saw the rise of the polis (city-states), the founding of colonies, the annexations by the Persian empire, as well as the first inklings of classical philosophy, theatre in the form of tragedies performed during Dionysia, and written poetry, which appeared with the reintroduction of the written language. This cultural flowering caused a multiplicity of differentiation. There are breaks and internal tensions within the mental universe of Greece in the following Classical period as well, as the winners of power-struggles revised the historical myths which were responsible for distinguishing one domain from another (Vernant, 1979). During these centuries of dissemination, the narrative stories were finally recorded in written forms such as the Homeric Hymns, Hesiod's Theogony, Works and Days and other poems, dramas, shows, historical and philosophical works. It is in and through written literature that this type of discourse reached later generations. However, when these authors of literature turn these narrative stories into written language, myths no longer communicate the viewpoints held by those who originally narrated them, but take on the ideas of the writers. Willcock, for example, suggest that Homer invented some of the details of the Iliad (Willcock, 1976) whilst even in terms of one author, Hesiod's two books contain quite different versions of the same story: Prometheus' theft of fire (Vernant, 1979). It seems, therefore, that the original plot and meaning of such myths may well have changed from the original oral tradition when the work was finally solidified in writing.

The concept of myth that we have inherited from the Greeks belongs, by reason of its origins and history to a tradition of thought peculiar to Western Civilisation in which myth is defined as fiction (Vernant, 1979). It is not until the 19th century that the first scientific theories of myth started to appear (Segal, 2004). Most consider myth in opposition to science. E. B. Tylor for example, asserted that human thought evolves through various stages, gradually progressing from the mythological to the scientific ideas. So myth and science are incompatible.

The anthropologist James G. Frazer took a similar position to Tylor, explaining that myth is part of primitive religion which is part of philosophy, itself universal; and primitive religion is the counterpart to natural science (Segal, 2004). Frazer saw myths as a misinterpretation of magical rituals, which were themselves based on a mistaken idea of natural law (Segal, 2004). The French philosopher and armchair anthropologist Lucien Levy-Bruhl saw an even wider division between science and myth. Like Tylor and Frazer, he associated myth with religion, which he considered primitive. The difference between them was that Tylor and Frazer subsume both religion and science under philosophy, while Levy-Bruhl assumed philosophy to be thinking freed from mystical identification with the world (Segal, 2004, 26). French anthropologist Claude Lévi-Strauss seemed to agree with his predecessors that myth is the epitome of primitive thinking (Segal, 2004), yet unlike Levy-Bruhl, he did not see it as entirely opposed to scientific thinking, and unlike Tylor (1899) and Frazer (1890) he did not see mythical thought as being entirely superseded by science. Rather, Lévi-Strauss claimed that what he called 'wild' or 'untamed' thought - La Pensée Sauvage (1966) - survived in all of us, although in modern societies, it was only visible in the world of art.

\section{Myth in Chinese Thought}

In China, there is no tradition of opposing mythical to scientific thought as in the west. Rather, myth is most frequently discussed in relation to history, with the central issue being how historically reliable mythical accounts may be as descriptions of actual events in ancient China (Zhong, 1990, 581-586). China has many myths that remain well-known, from the ancient stories of 'The Bird Jingwei That Tried to Fill the Sea' (精卫填 海) and 'The Foolish Old Man Who Wanted to Move the Mountains' (愚公移山), to stories from the end of the Qing Dynasty such as 'Journey to the West' (西游记) and 'The Story by the Water Margin' (水湤传). Whilst these well-known stories derive from the majority Han ethnic group, many other ethnic inhabitants have their own myths, and people in one place often cannot tell the stories of another. Some of these stories share commonalities with myths and legends in other parts of the world. Significantly, within the Chinese education system, myth and history are not rigorously separated, and as a result, it is widely accepted that mythical stories, or central elements of them, have a factual basis, although there is little historical evidence to support such a belief. For example, both during the fieldwork in Yunnan and my periods of study in Beijing, it is found that whilst few of those with whom I discussed my mythological interests believed that the Bird Jingwei was really able to fill the sea, the idea that Jingwei was the spirit of Emperor Yan's drowned daughter was usually accepted without question. It was within this broad context, then, that I undertook fieldwork on the myths of the She people of south-eastern China. 


\section{The She Mythic Tradition}

The She people form one of the 56 ethnic groups officially recognized by the People's Republic of China in 1956, although their history extends back centuries earlier. The earliest genealogical booklet recorded that She people revolted against their oppressor as early as the Tang Dynasty in the $7^{\text {th }}$ century (Zhejiang Ethnic Affairs Commission, 1992). The name 'She' is a Chinese Han appellation meaning 'slash and burn', specially referring to their mode of horticultural production. The She invariably designate themselves as Sanhak (山哈) which means 'the guest of the mountain'. Their view of the mountain as their host accords with Ellen's (1986) and Milton's (1996) assertions that different societies, regard Nature in their own image, sometimes benignly, sometimes with hostility, but rarely with indifference. By their own account, the She were forced to migrate to the hills to escape from the discrimination of other tribes and to protect themselves by geographic isolation. Now they occupy the mountain areas in the southeast part of China, mainly consist of south of Zhejiang Province, west of Fujian Province and northern part of Canton Province. (See maps below.)

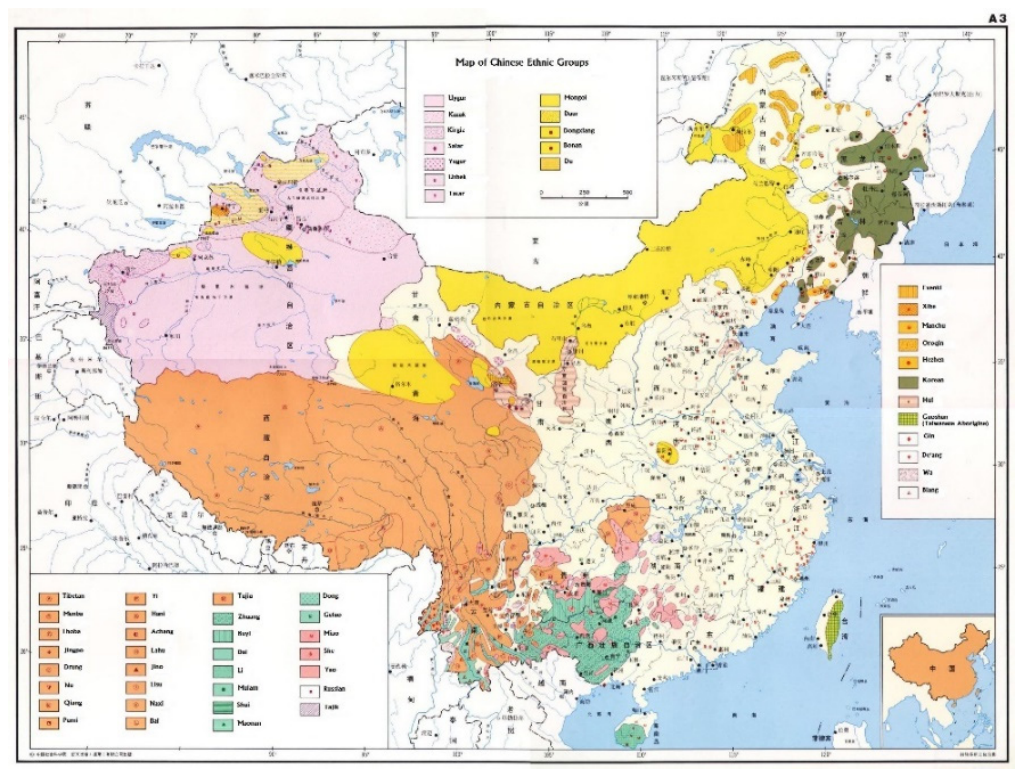

Map 1. Ethnic groups within China (Hao, 2002, A3)

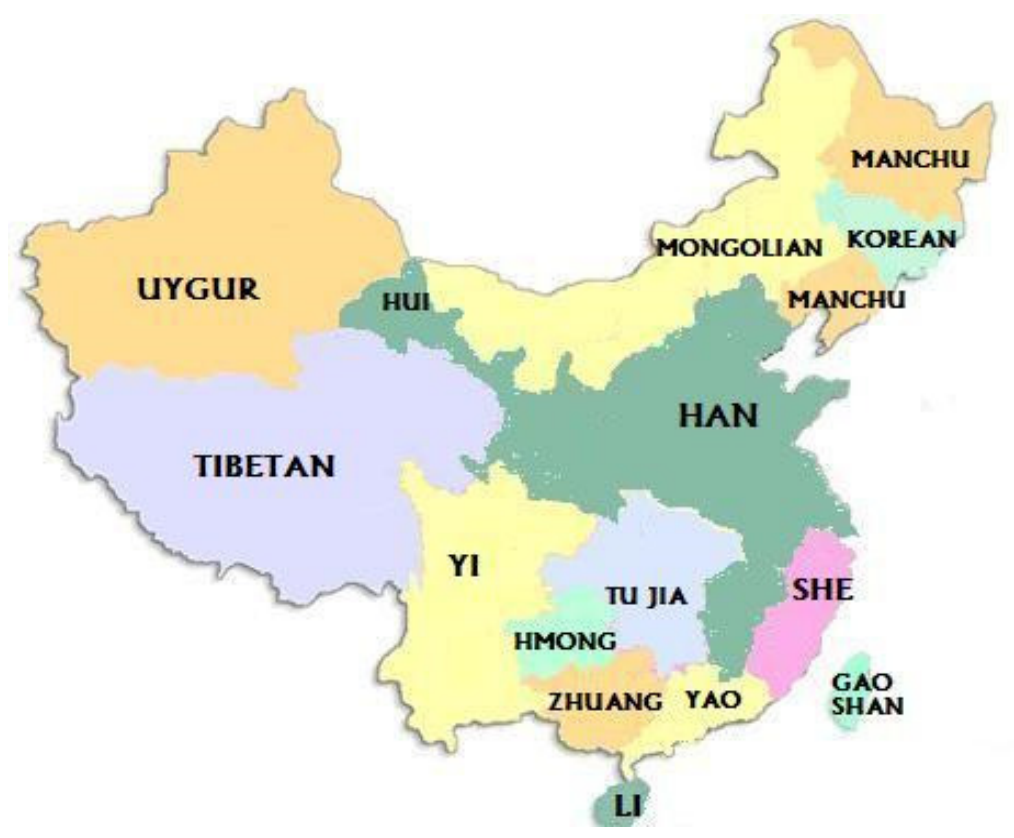

Map 2. Simplified map of ethnic group distribution in China (Author, after Hao, 2002) 
In the summer of 1929, a German professor Hans Stubel went to Jingning Zhejiang Province, a county inhabited by She people, with his student Li Huaming - a teacher in the school of physiology in Tongji. Later they published a book named Investigation of She people in Zhejiang Jingning Chimu Mountain (1933) recorded the She clans, surnames, people and cultures in this county. Using the work of Stubel and Huaming as a base for comparison, my fieldwork was held in the same county over two periods. The first period was just three days spent at a temporary exhibition with the theme of 'Sanhak Charm' displayed in Zhejiang Shaoxing Museum from January $27^{\text {th }}$ to $29^{\text {th }}$ 2014. The primary objects on display came from Zhejiang Museum and Lishui Museum, and the main aim of exhibition, which lasted from January $26^{\text {th }} 2014$ to March $10^{\text {th }} 2014$ was to raise the awareness of the public in Zhejiang of the She ethnic group, as it is the only ethnic minority group in Zhejiang Province and the government is officially committed to preserving their surviving culture. The exhibition was divided into four parts, history, religion, production customs and daily life. This was my first contact with She people and their culture, and led me to the decision to visit the only She autonomous county, Jingning Lishui, Zhejiang. The second, and major period of fieldwork took place from June to September 2014 in a small valley in the She autonomous county, where I stayed with She people for more than 70 days. During this period, myths were collected and investigated to prove how She people preserve and transmit and deploy their stories in contemporary society.

The She group is not the only ethnic group in China which has their own epics in China, but it is unique in being the only one to create graphic depictions matched with the narratives they tell. The She people regard these two cultural forms in very distinct ways: whilst the pictorial representations which preserve the core elements of the myths are venerated and usually found in sacred contexts such as temples, the oral narratives are flexible and can be creatively adapted by storytellers. Before examining in more detail how the She people have made use of this heritage in both past and present, it is first necessary to outline the central narrative of She mythology: the Song of Gao Huang (高皇歌) or Gao Huang Ge.

The Gao Huang Ge describes the origins of the She people's ancestors.

The myth begins in the time of the God-Emperor Gao Xin, whose wife had a severe pain in her ear. The emperor summoned doctors who discovered a bloody ball in the queen's ear. The doctors plucked out the ball, which grew rapidly into a beast with the head of a dragon and the body of a unicorn, named Panhu. Years later, invaders attacked the kingdom, overcoming all resistance. Emperor Gao Xin promised that the person who could protect the homeland against these enemies could marry the princess. The dragon-unicorn took up the challenge and defeated the invaders. After his return, Panhu married the emperor's daughter and became his successor. Panhu and the princess had four babies, which were given different surnames by the emperor. As their father migrated from one area of southeastern China to another, they each settled in a different area where they started their own families, which are the ancestors of the present-day She groups in these provinces. Panhu was appointed to rule Canton Province, before finally going to study under a Taoist priest.

The following group of pictures, now held by Zhejiang Museum, portray scenes from this myth.

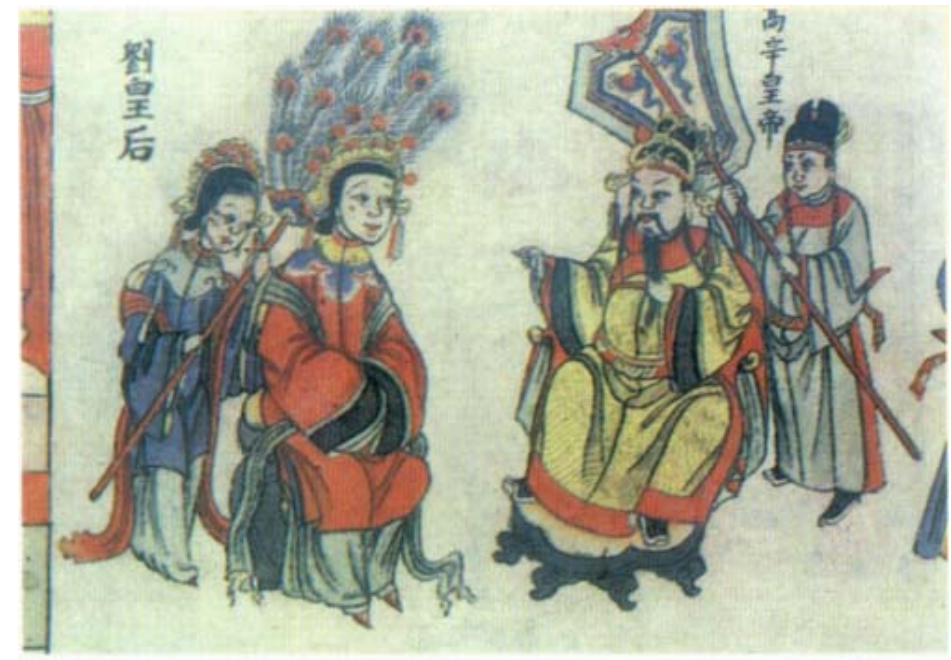

4 - 1、高辛当朝

Figure 1. The Emperor Gao Xin had a queen who was called Liu 


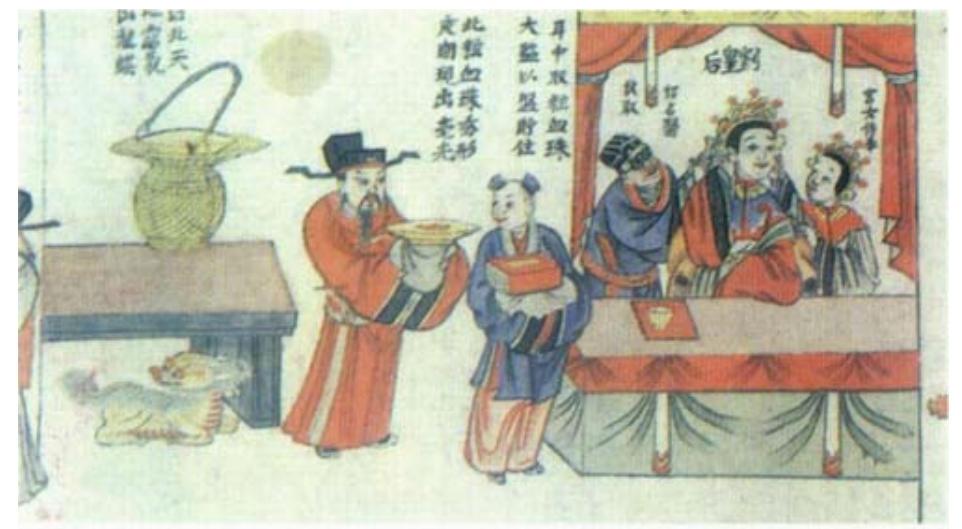

\section{$4-2$ 、龙麒出世}

Figure 2. The Queen suffered pain in her ear. Doctors were called and extracted a bloody ball. The blood ball started to grow, and in a sudden flash, turned into a dragon-unicorn, named Panhu

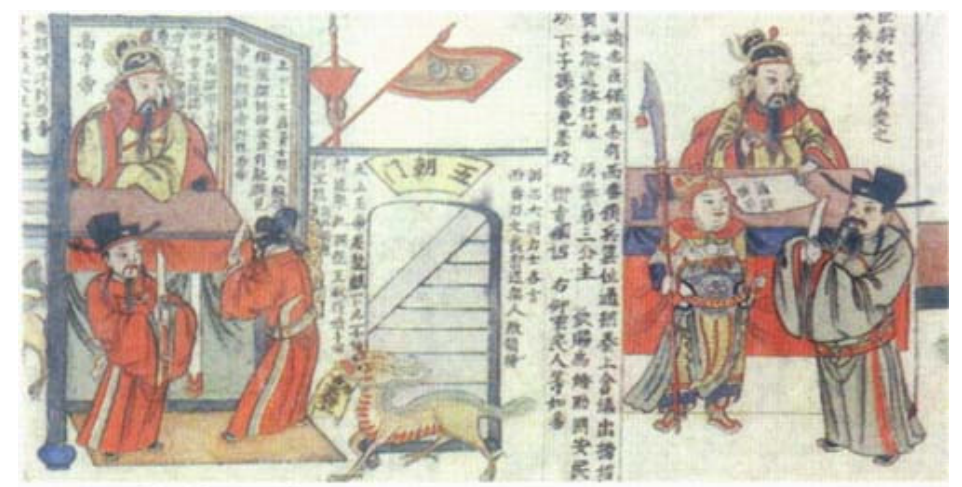

4-3、拆榜征番

Figure 3. When invaders entered the kingdom, nobody dared to resist, but the dragon-unicorn promised to defend the kingdom against its enemies

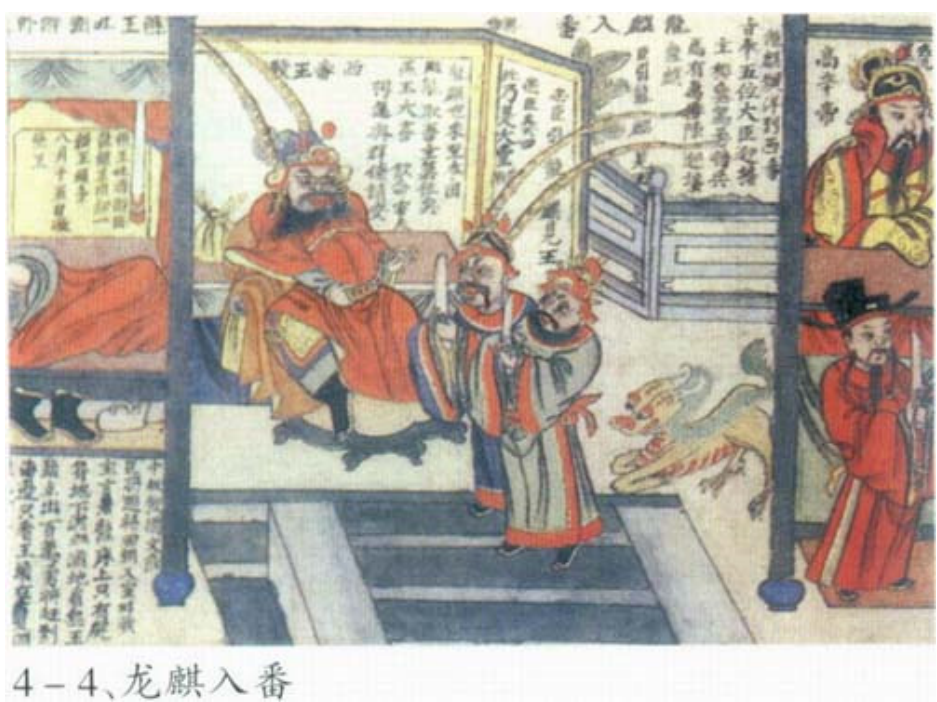

Figure 4. Panhu did not use any armies; instead, he entered the camp of the invaders alone and gained the trust of their leader. Panhu then killed the invader's leader by biting his neck while he was sleeping. The invaders were defeated without any soldiers or weapons 


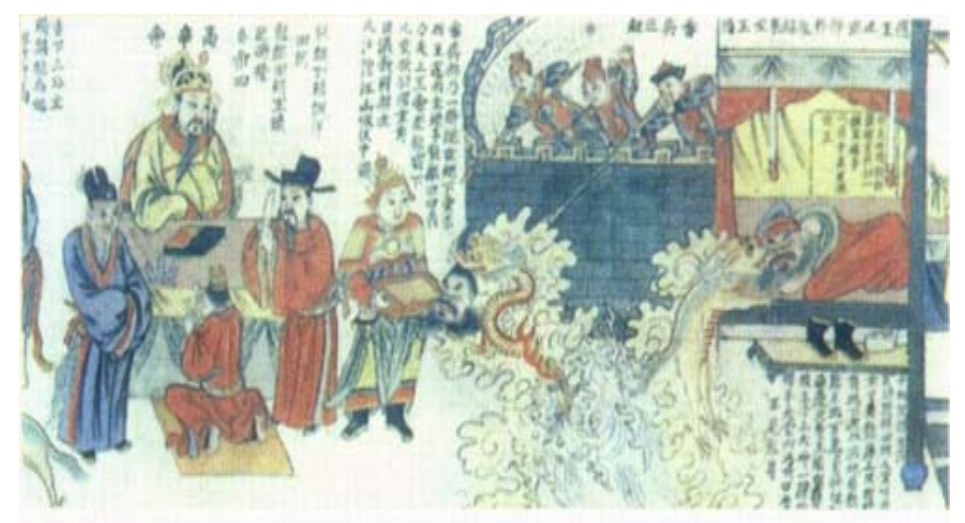

$4-5$ 、归朝奉献

Figure 5. Panhu took the head of the leader, and returned to present it to the Emperor

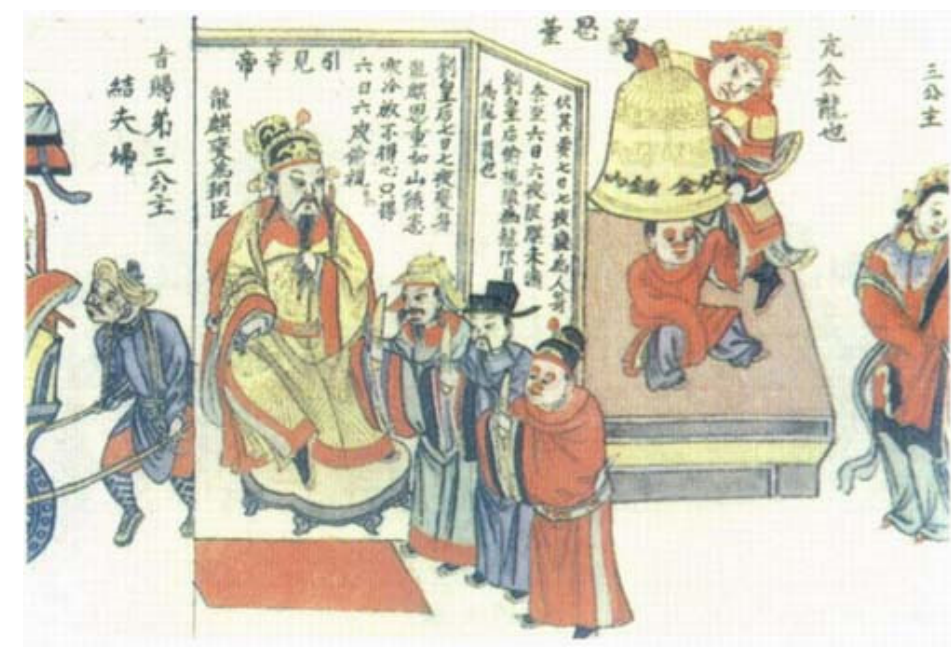

$4-6$ 、金钟变身

Figure 6. Gao Xin rewarded the dragon-unicorn with by giving him his third daughter in marriage. The day before the wedding, Panhu transformed into a man, crowned by a large bell

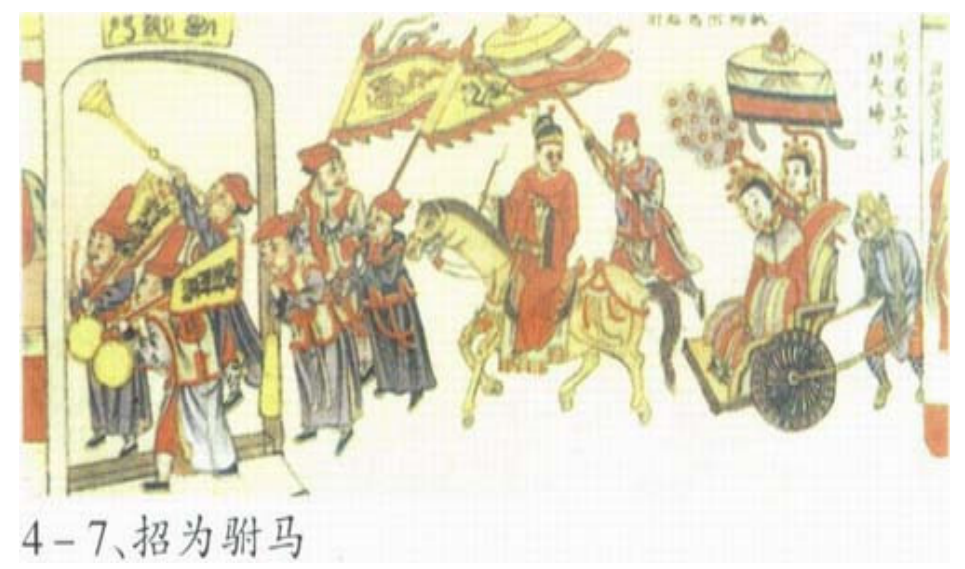

Figure 7. The marriage was celebrated with a large party, and Panhu became the prince of the kingdom 


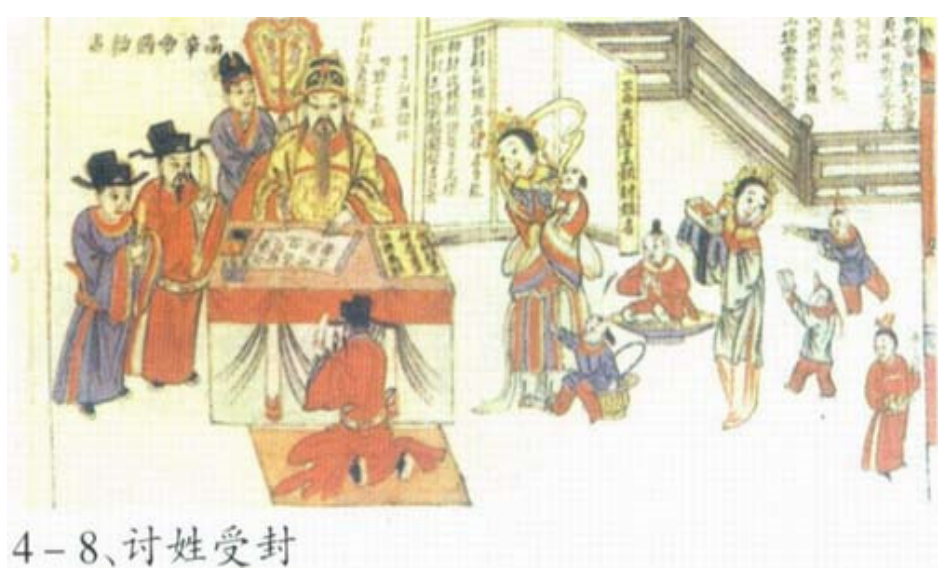

Figure 8. Panhu was given surnames for his four children by the Emperor Gao Xin

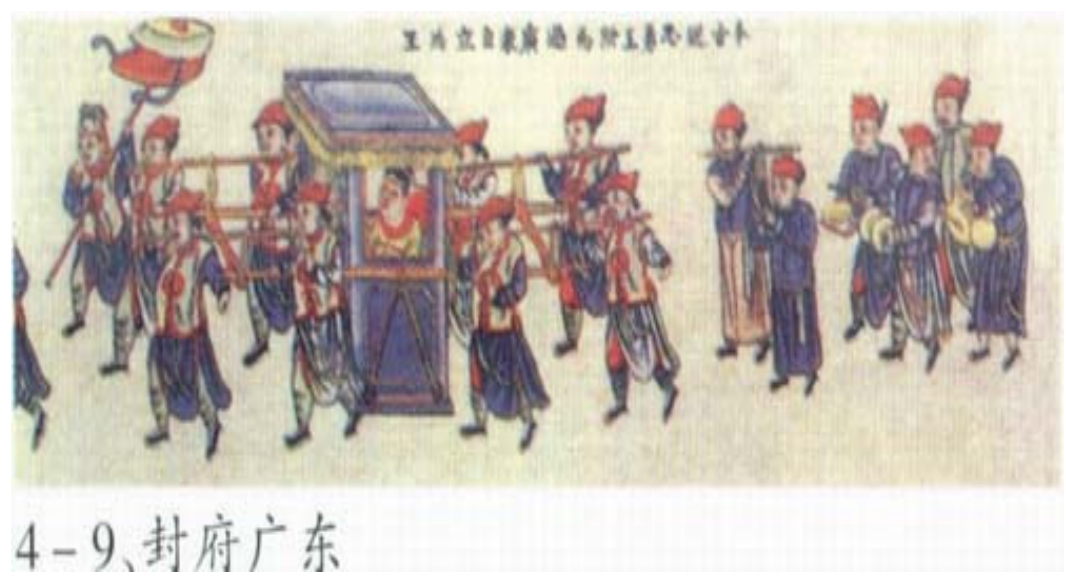

Figure 9. Panhu was made ruler of Canton Province, and moved his whole family to this area

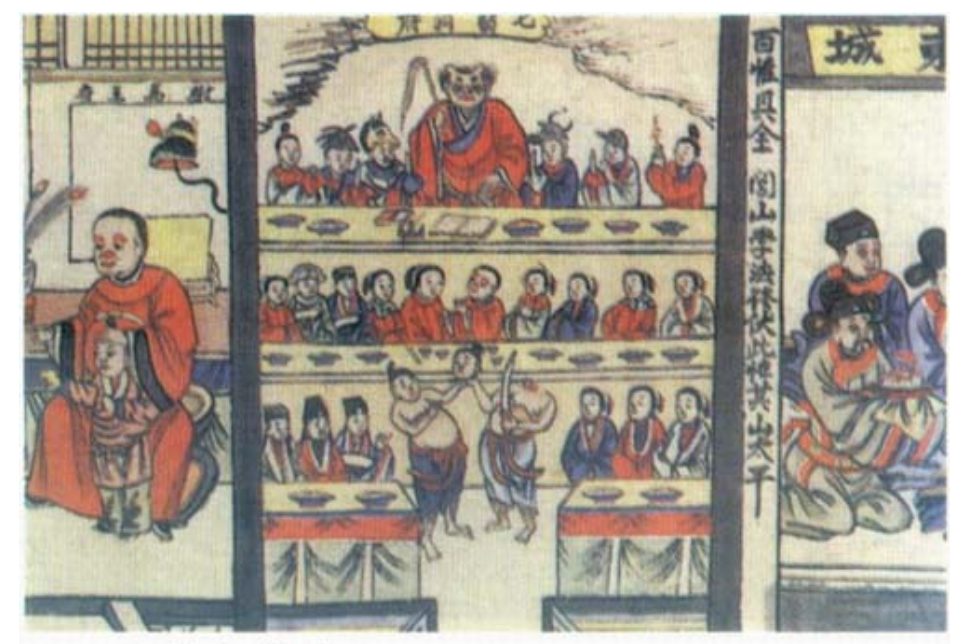

4-10、闾山学法

Figure 10. Later, Panhu went to the mountains to learn skills from a Taoist priest 


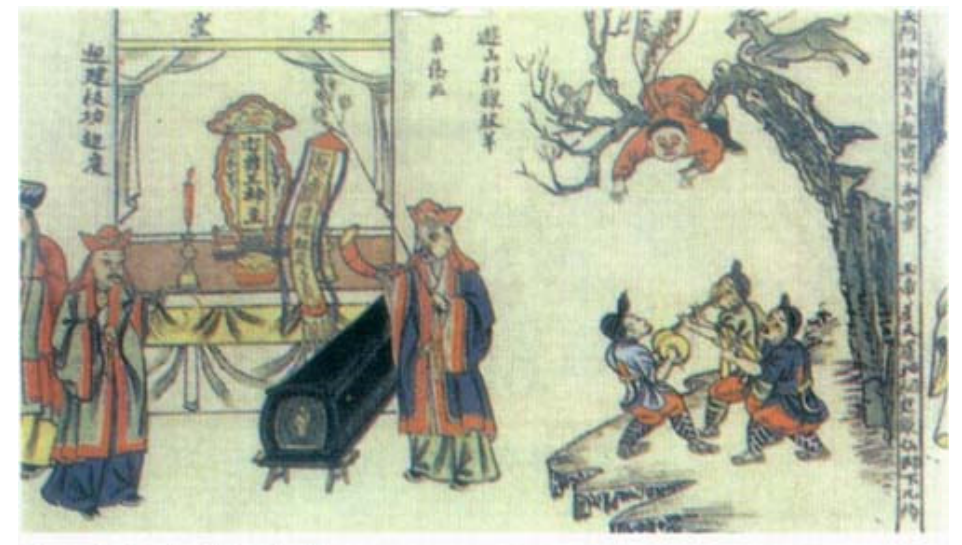

\section{4 - 11 、打猎殉身}

Figure 11. Panhu was killed accidentally when hunting

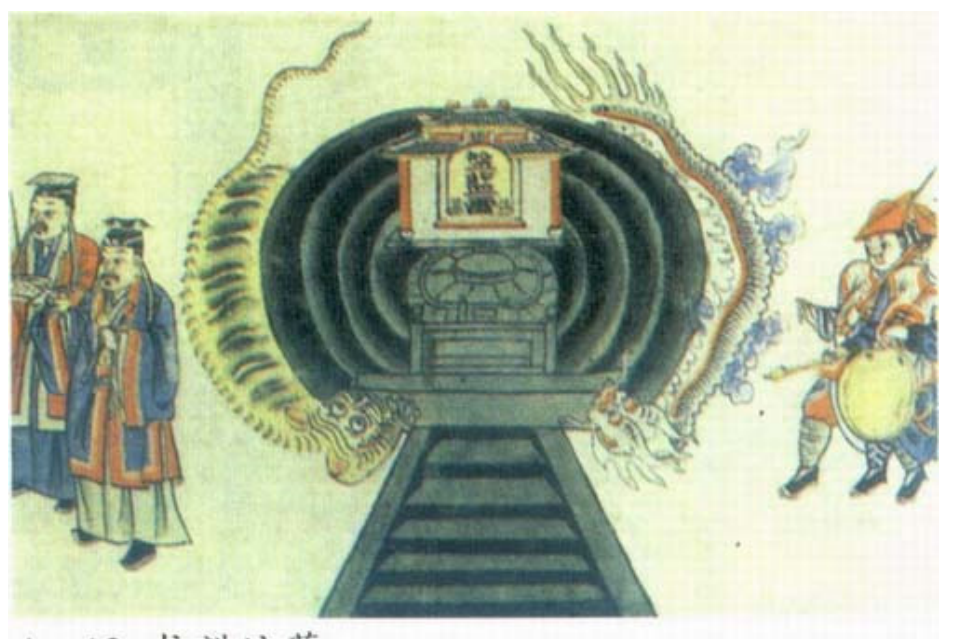

$4-12$ 、龙豦坟墓

Figure 12. His offspring buried his body and built a tomb for him in Canton Province

Epics such as the story of Panhu are most frequently passed on through oral narrative, but some of them can be found recorded in illustrations in family pedigree books or inscriptions on stones as well. From this point of view they share similarity with myth in form and characters. For example, the epics are usually told during rituals offering sacrifices to the ancestors. As such rituals are organised every year in every family during the Spring Festival, they vary from area to area. I will take a ritual in Zhejiang Province as a case study, which has been categorised as part of the province's intangible cultural heritage. Almost all of rituals hosted by She people in Zhejiang area move through three stages: first proposing a toast to the ancestor, then bowing to Heaven and Earth, after which the oldest person, respected as the most knowledgeable in the group, will sing the epic. Not only the rituals, but also the epics narrated by elders vary significantly from one area to another. It is becoming a concern that there are fewer elders left who can sing the epics required in sacrifice ceremonies, and although the plot-lines and lyrics are recorded in archival literature, there is a fear that the oral rhythm of the epics may not be passed on to future generations.

The images associated with epics take a variety of forms. Most of the versions presented here were painted on white cotton cloths which were either inserted at the beginning of genealogical-tree books, or used in ancestral temples for decoration. The core character in these pictures is the hero-figure of the dragon-unicorn, regarded by She people as divine. Figure 13 shows a carved wand, of a type which is invariably enshrined at the center of ancestral temples. The figure of the dragon-unicorn is carved at the top of the wand. The dragon-unicorn, then, has come to be seen as a logo of the She people: a symbol referring to their historical roots. In understanding the relationship between the epic tales, their pictorial representations, and the symbolic objects associated with them, 
we may turn to Levi-Strauss's $(1986,18)$ discussion of image, sign and concept (Levi-Strauss, 1966, 18). He pointed out that the sign is the intermediary between images and concepts, signs resemble images in being concrete entities but they resemble concepts in their powers of reference. Concepts have an unlimited capacity in being substituted for something else. If She ancient graphics could be referred to image, the epic is metaphorised into concept, and the wand and similar sacred items may be seen as the signs which mediate between them.

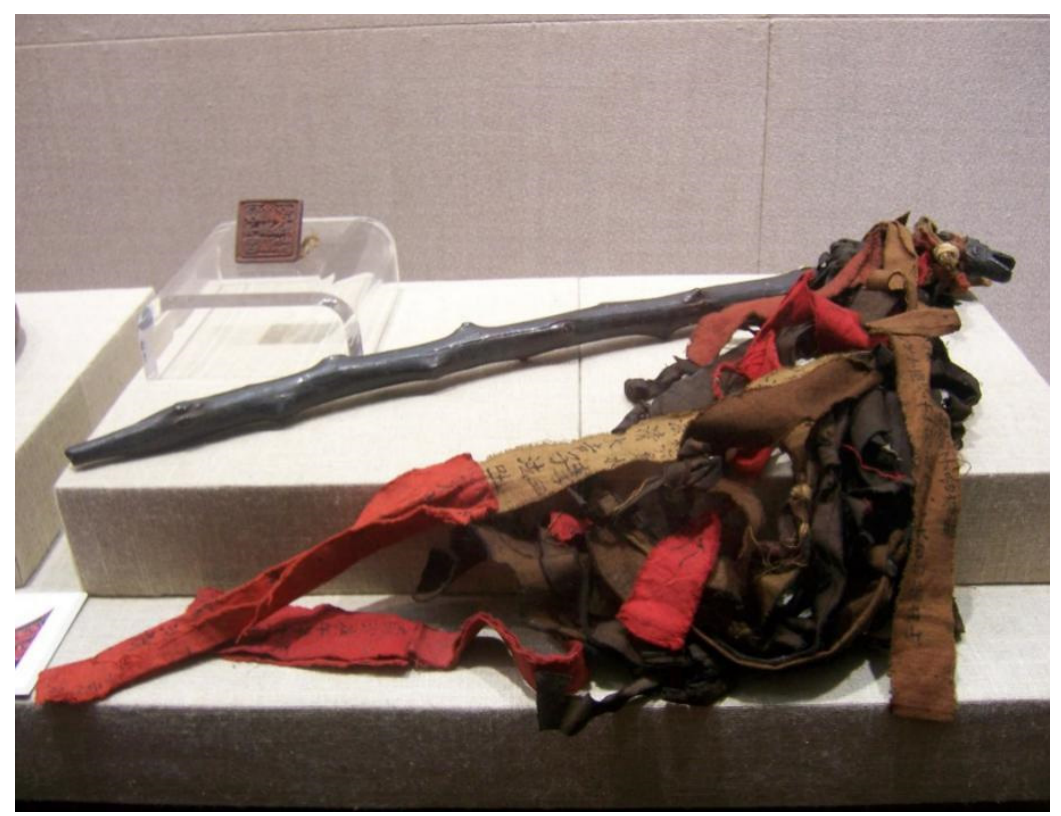

Figure 13. Carved wand featuring dragon-unicorn (Photo by author: 27 January 2014)

The final part of this paper will examine the transmission of She oral narratives in the past and present, and show how the She rationally deploy their mythic heritage to achieve both material and symbolic ends within the context of the modernizing Chinese state.

\section{Myth in the Modern She World}

When exploring the transmission processes by which She epics are passed from one generation to another, a young She man, who told me that for most of his generation, myths are not learnt orally from elders, but from descriptive books produced by Han Chinese people. The She, then, recognise themselves first from the descriptions of others. This is not a new phenomenon, since She myths appear to have been based on Han narratives produced during the period from the Han to the Qing Dynasties, and reconstructed by the She. By comparing stories collected from She areas with those recorded in Han classical literature, I will suggest that the She have engaged in a process of transformation and re-evaluation of the kind described by Lévi-Strauss (1963,). This process can be seen through three aspects of these epics.

The first of these aspects is the rational modification of the myth's content. According to Boas (1898) "it would seem that mythological worlds have been built up only to be shattered again, and that new worlds were built from the fragments". This idea of myth as composed of discrete elements which could be combined and recombined in different ways to produce different meanings was developed by Lévi-Strauss (1963), who regarded myths as analogous to language, with its discrete elements of phonemes, morphemes and sememes, asserting that "there are gross constituent units in a higher and more complex order in the myth, and more specifically they are bundles of relations". Lévi-Strauss $(1978,3)$ suggested, therefore, that "Its basic structure is the same, but the content of the cell is not the same and can vary". The Han classical work on which the epic of Panhu appears to be based, Fengsutongyi (General Discussion about Customs), published about 189AD during the Han Dynasty, describes the origin of the She people and mentions an emperor who raised a dog with colourful fur. The dog was named Panhu (Ying, 2010). Another book Sou Shen Ji (History of Searching for God) recorded the story with more details: "The wife of Gaoxin suffered pain in her ear, from which the doctor extracted a worm-like object, putting it on a plate and naming it Panhu (meaning the worm in the plate). Then the worm became a dog with colourful fur."'(Gan, 1979) Several hundred years after the publication of 
Fengsutongyi, stories of Panhu appeared in books, using Han Chinese characters, which were produced by She people themselves (Lan, 2011). In the She versions of the story, however, the dog was transformed into a dragon-unicorn. Whilst the dog is seen by the Han as a mundane and humble animal, the dragon and unicorn are both mythical creatures regarded as highly prestigious. The transformation of the humble dog into the prestigious dragon-unicorn may be seen as a rational move which makes the content of the epic more acceptable to younger generations of She. In Lévi-Strauss's (1973) words, the notion of 'myth' can include everything we are thinking, as we use this word randomly to refer to natural phenomena, products of oral literature, philosophical speculation, and other cases through which we can realize linguistic processes. The She, then, adapted the Han version of the legend of Panhu to be compatible with their own imaginings of their history and daily life.

Another example of rational modifications to the myth is in relation to migration routes. In each area, She people would add their own migration route to the end of the story, so the epic would make sense to their children. According to Lévi-Strauss (1963), the kind of logic in mythical thought is as rigorous as modern science. The She people modify their myths in rational ways, therefore, so that the fantastical elements set in ancient times connect to the known history of more recent periods.

The second aspect of She mythology in which transformations may be observed is in the graphical depictions of the myths. Whilst orally told epics are modified in rational ways to connect to the known history and lived experience of particular groups, the graphical depictions: the group's signs, are regarded as sacred and are not subject to modification. Nevertheless, there is evidence that transformations have taken place in the past. The most meaningful figure depicted is that of the dragon-unicorn, venerated as a symbol of the She people. The paper above has showed how the She people transformed the animal from dog to dragon-unicorn, regarded as a more dignified creature by the dominant Han group. Why, however, did the She choose this specific animal rather than others? Lévi-Strauss notes that there is no direct relationship, based on contiguity, between man and totem. The only possible relationship must be 'masked', and thus metaphorical (Lévi-Strauss, 1973). From this metaphorical perspective, we can offer an explanation for the choice of the dragon- unicorn as the crucial character of their signs. Since neither dragon nor unicorn are actually existing creatures, their extraordinary rarity makes them creatures of high-status, and the dragon is the symbol of the dominant Han group in China. The choice of the dragon merged with the unicorn suggests that the She are asserting a status equal or greater than that of the Han. A similar explanation may be advanced for the frequent use of another non-existent creature, the phoenix, in She embroidery and women's hair accessories (see Figure 14). The phoenix is a mythical bird which is widely known in many cultures, its crucial feature being that does not die, but is reborn in fire, more beautiful than before. In China, the phoenix has the same status as the dragon, but represents the female principle, in contrast to the masculinity of the dragon. As the She were traditionally a matrilineal society, the phoenix is particularly important to them, and is paired with the male dragon-unicorn as a symbol of She female identity (Pangjin, 2007).

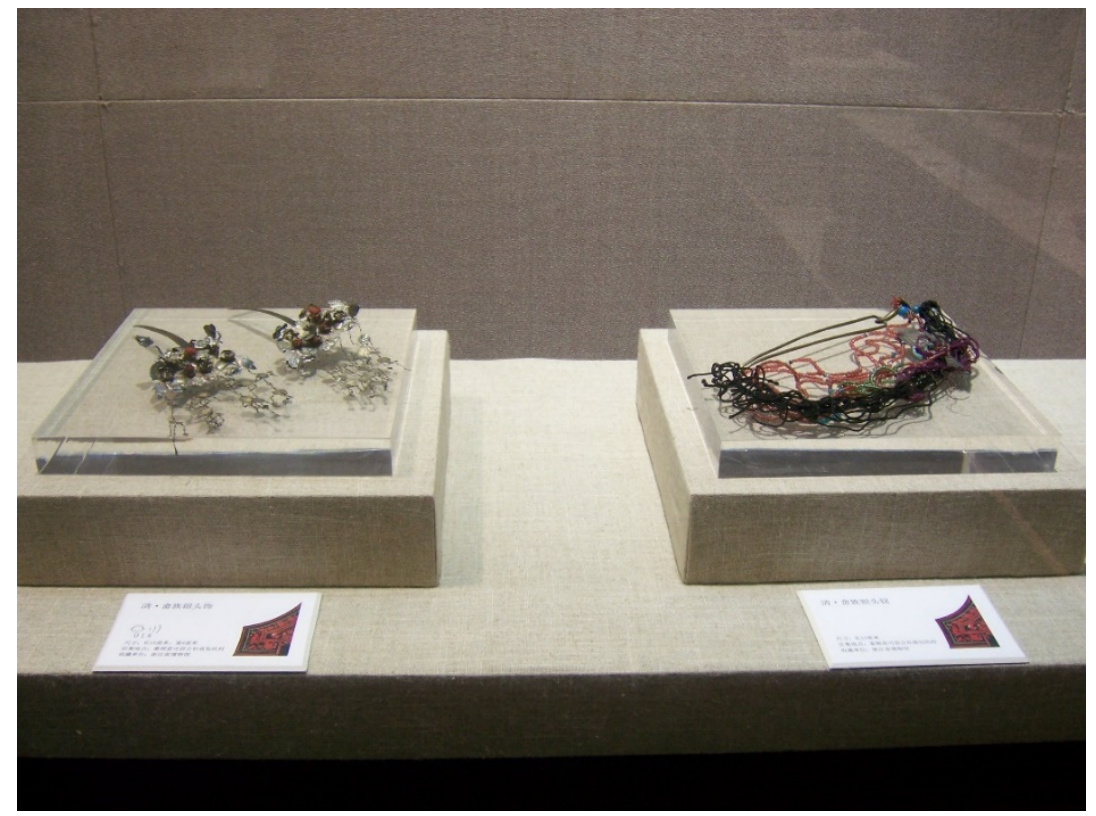

Figure 14. Women's ornaments featuring the Phoenix (Photo by author: 27 January 2014) 
What then, of the dog, which featured in the classical Chinese references to the She? In fact, whilst the Han regard the dog as a humble animal, it is respected by the She, who see it as a symbol of loyalty and honesty, and its status amongst the group is no less than that of the dragon-unicorn. Statues in the ancestral temple pictured below (Figure 15) portray She men accompanied by a dog, and most of the She villages visited by ethnologists in Zhejiang Province prohibit the eating of dog meat, as do many of the She villages in parts of Canton Province.

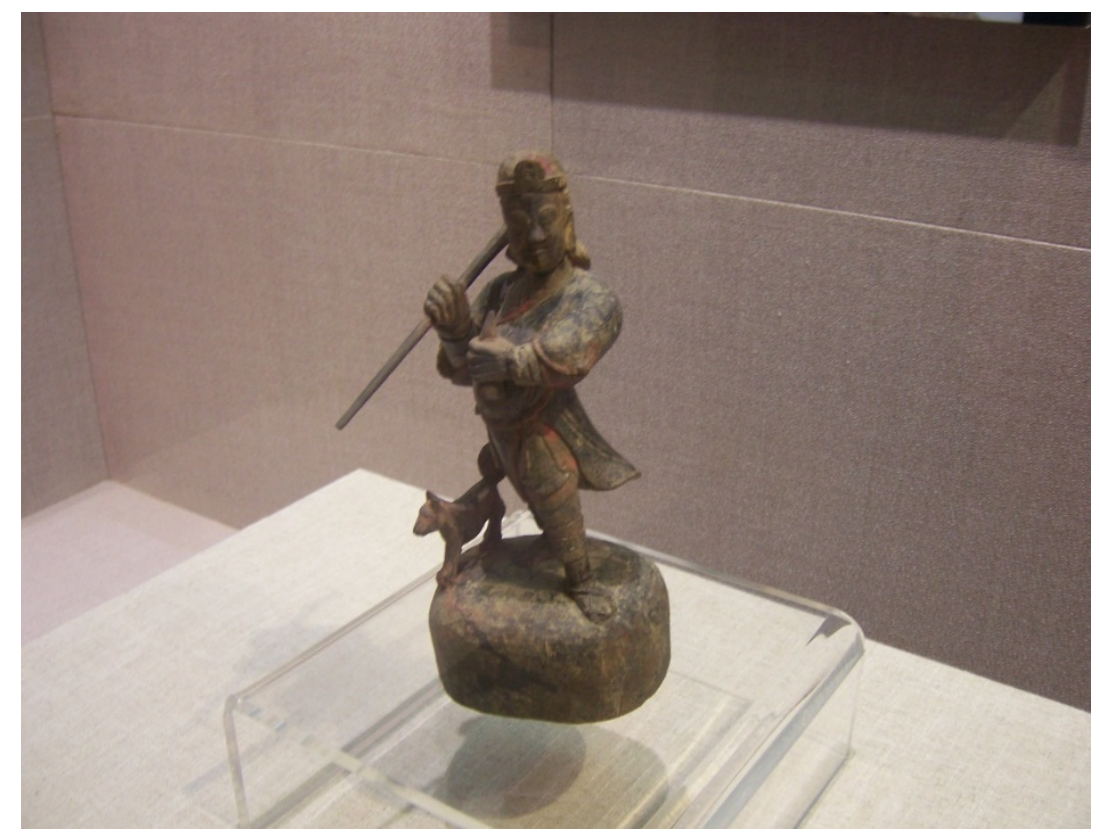

Figure 15. Statue of She man accompanied by a dog in ancestral temple (Photo by author: 27 January 2014)

The English trader and interpreter Long, speaking of the Ojibwa at the end of the eighteenth century, declared that there was confusion between clan-names and beliefs concerning guardian spirits (Levi Strauss, 87, 1973). Similarly, in this case, the dragon-unicorn, like the phoenix, could be seen as symbols of the She group, and the dog could be seen as a guardian animal. Supporting evidence for this interpretation is found in a document, preserved by Hui Chang Bureau of Religion and Nationality about a dialogue between the officers and a 75 -year old She person named Lan Huajin in 1985 (Cao, 2014):

when I was young, about ten years old, I was told by my grandpa, that we have the surname of Lan, were forbidden to eat $\operatorname{dog} . .$. as we immigrate from Fujian Province, and there was a spirit tablet in the all ancestors' temples, it is said that dog was the guardian god of She...

The differences between animals seen as symbolic representatives of the group and those seen as guardians may not have been apparent to outsiders such as the Han, however, who may have seen these animals venerated at festivals and rituals, without fully understanding the meanings attached to each.

The third aspect of She mythology in which transformation and re-evaluation are evident is in the process of narration. When recounted by others, such as the Han, She epic stories may seem strange and unbelievable, but when narrated by the She themselves, the stories take on a greater power due to the storyteller's ability to fill the tale with emotion and relate it to his audience. Although the structure of the story may be fundamentally the same, the meaning and emotional content is reconstructed from their own perspective, as is apparent in the position of the narrator. In Han narratives, the third person is always used. The narrator is thus situated as an outside observer, looking at, and sometimes looking down on, the lives of other ethnic groups. When the materials created by the Han writers are reused by the She, however, the subject is shifted from the third to the first person, so the stories are told from their own standpoint. "The substance of myth", Lévi-Strauss observes, "does not lie in its style, its original music, or its syntax, but in the story which it tells" (Levi Strauss, 210). It is suggested that the content of the story, on which Lévi-Strauss focuses, includes not only the plot, but also the emotion that the narrator conveys to the audience. She storytellers, then, add what seems rational to them, and leave out what seems meaningless or absurd. Lévi-Strauss (1963) also notes "that a fairy tale is nothing more than a narrative that puts into words a limited number of functions in a constant order of succession ... nothing 
prevents the making up of tales where fairies have a role, without the narrative's conforming to the rules". Myths, then, have to be made. She people draw from the epic narrations they have heard told by the older generation in ceremonies, in records in their own family books, and in the artefacts and rituals in the ancestral temples, in reconstructing these myths for themselves. Even though the stories were originally based on Han classical literature, and today's She may learn them first in Han schools, She renditions are based on their own sources, rather than the versions told by the Han. It is due to the rational adaptation of narratives so that they continue to make sense in the modern world.

\section{Conclusion}

The epics of the She not only serve to preserve their ethnic identity and assert their prestige in the context of continuing Han domination within the modernizing state, but may also be deployed for material ends in interaction with that state. Over the next few years, the village, in association with the government, is going to develop a tourist route based upon the investigations of Stubel. The project will include the building of a museum dedicated to Panhu and the origin myths of the She, as well as the reestablishment of the accommodation in which Stubel once lived. It is also intended that visitors will be able to interact with locals to experience the song, dance, customs and culture of the She people. The She clearly hope that the project will bring both material benefits and prestige through the public performance of the myths which in the past have served to keep alive She identity and pride and which still retain that function today. Whilst Lévi-Strauss saw mythical or 'wild' thought as confined to the world of art in the modern world, in contemporary China, myth may be seen as a significant and sometimes central element of Chinese modernity.

\section{References}

Annoymous. (1978). Myth and meaning. London (etc.): Routledge and Kegan Paul.

Boas, F. (1898). "Introduction" to James Teit, "Traditions of the Thompson River Indians of British Columbia." Memories of American Folklore Society.

Cao, D. M. (2014). Reconstruct She people, Beijing: China Publishing Group Corp. 曹大明. (2014).重塑鈿人. 北京: 世界图书出版公司.

Clarke, S. (1981). The Foundations of Structuralism: a Critique of Levi-Strauss and the Structuralist Movement. The Harvester Press / Barnes \& Noble Books.

Cruz, L., \& Frijhoff, W. (Eds.) (2009). Introduction: Myth in history, history in myth, Proceedings of the Third International Conference of the Society for Netherlandic History New York: June 5-6, 2006. Myth in History, History in Myth. Leiden, Boston: Brill.

Ellen, R. F. (1986). What Black Elk left unsaid: on the illusory images of Green primitivism. Anthropology Today 2.

Fowler, H. W., \& Fowler, F. G. (1995). The Concise Oxford dictionary of current English. Oxford: Oxford University Press.

Gan, B. (1979). In S. Y. Wang (Trans.), History of Searching God. Beijing: Zhonghua Book Company. 干宝. (1979).汪绍楹校注: 搜神记. 卷十四. 北京: 中华书局.

Hao, S. Y. (2002). Atlas of Distribution of National Minorities in China. Beijing: Sinomaps Press. 郝时远. (2002). 中国少数民族地图集. 北京: 中国地图出版社.

Herodotus. (1987). The History. Chicago, London: University of Chicago Press.

Lan, L. (2011). Art value of She Ancient Graphs. Studies in Culture and Art, 4(1). 蓝岗. (2011).蕃族祖图长卷 艺术价值初探. 文化艺术研究, 4(1).

Lévi-Strauss, C. (1963). Structural anthropology vol.1, New York: Basic Books.

Lévi-Strauss, C. (1963). Structural anthropology vol.2, New York: Basic Books.

Lévi-Strauss, C. (1966). Savage mind. London: George Weidenfeld and Nicolson Ltd.

Lévi-Strauss, C. (1973). Totemism. Harmondsworth: Penguin.

Malcolm, M. W. (1976). A Companion to The Iliad. Chicago: University of Chicago Press.

Milton, K. (1996). Environmentalism and cultural theory: exploring the role of anthropology in environmental discourse. London: Routledge. 
Nevena Dimitrova, P. (2013). From Logos to 'Dialogos': the Problem of Ignorance and the 'Dialogical' Knowledge According to St. Maximus the Confessor. Communio viatorum.

Pang, J. (2007). Chinese Phoenix Culture. Chongqin: Chongqing Press. 庞进. (2007). 中国凤文化. 重庆:重庆 出版社.

Segal, R. A. (2004). Myth: A Very Short Introduction. Oxford: Oxford University Press.

Vernant, J. P. (1980). Myth and Society in Ancient Greece. Brighton: Harvester Press; Atlantic Highlands, N.J.: Humanities Press.

Ying, Z. (2010). In L. Q. Wang (Trans.), General Discussion about Customs. Beijing: Zhonghua Book Company. 应劭. (2010). 王利器校注：风俗通义・佚文. 北京: 中华书局.

Zhejiang Ethnic Affairs Commission. (1992). Gao Guang Song of She Group. Beijing: China Radio \& Television Publishing House. 浙江省民族事务委员会. (1992). 畜族高皇歌. 北京：中国广播电视出版 社.

Zhong, J. W. (1990). Discussion about Epics, Study of Gelsall. Gansu: Gansu Ethnic Press. 钟敬文. (1990). 史 诗略论. In 赵秉理 (Ed.), 格萨尔学集成 (Vol.1), 甘肃民族出版社.

\section{Copyrights}

Copyright for this article is retained by the author(s), with first publication rights granted to the journal.

This is an open-access article distributed under the terms and conditions of the Creative Commons Attribution license (http://creativecommons.org/licenses/by/4.0/). 